\title{
Dakwah: Priyayi dan Santrinisasi
}

\author{
Muh. Sungaid \\ UIN Syarif Hidayatullah Jakarta \\ muhammad.sungaidi@uinjkt.co.id
}

\begin{abstract}
Abstraks: : Aset budaya keraton mulai dari naskah kuno, benda-benda pusaka, karya-karya arsitektur sampai karya seni dijaga dan dirawat dengan baik. Banyak negara di sektor pariwisatanya berkembang pesat dengan mengangkat kekayaan tradisi, narasi atau cerita yang menarik tentang daerah itu. Aset budaya dan karya-karya adiluhung harus diapresiasi dan dilindungi, dijaga, dirawat, dan bahkan dikembangkan. ${ }^{1}$ Kekayaan budaya keraton Nusantara harus dilihat sebagai bekal dan modal untuk meraih kemajuan sebagai melangkah maju.Sebagai modal penyemangat persaingan global yang semakin varitif, sengit dan kompetitif. Dalam berbagai bidang ekonomi/ sosial, budaya, pendidikan, militer dan teknologi. Tulisan ini melacak penerapan nilai-nilai Islam, budaya dan demokrasi di keraton Kasultanan Yogyakarta pada saat kepemimpinan dipegang HB IX. Menjelang wafat, HB IX tidak meniru para pendahulunya dalam menentukan siapa yang menjadi penerus takhta Kasultanan ${ }^{2}$ dan proses demokratisasi dengan meleburkan tata kesultanan dalam Negara Kesatuan Republik Indonesia. Rahasia Yogyakarta bertahan itu karena proses sejarah dan sosiologi masyarakat yang berbeda dengan tiga bekas kesultanan lain (Surakarta, Deli, dan Bone).
\end{abstract}

\section{Permalink/DOI: http://doi.org/10.15408/dakwahv22i112064}

\section{Pendahuluan}

Indonesia adalah negara dengan jejak sejarah peradaban yang besar dan gemilang. Sejarah mencatat, kebesaran Kerajaan Mataram-Hindu dan Sriwijaya, yang berhasil membangun kekuasaan dan kekuatan maritimnya. Sejarah juga mencatat kebesaran dari Kerajaan Majapahit yang mempersatukan Nusantara. Misalnya, kebesaran Samudera Pasai, Demak, Mataram-Islam berni menyerang Belanda di Batavia. Sedangan kerjaan, Maluku, Bugis dan Tidore dengan kapal pinisi, pelaut-pelaut Nusantara mengarungi laut, menjelajahi Samudera Hindia, Benua Australia, dan Benua Afrika. 3

Keraton sebagai sumber kebudayaan telah melahirkan karya-karya seni yang luhur sebagai pencerminan identitas budaya bangsa dan merupakan aset nasional yang cukup potensial di bidang kepariwisataan. Para sultan, raja, pangeran, permaisuri, dan abdi dalem memperoleh "amanah" warisan peradaban Nusantara yang bisa dijadikan modal budaya untuk menghadapi tantangan bangsa ini, baik saat ini maupun di masa mendatang.Aset budaya keraton mulai dari naskah kuno, benda-benda pusaka, karya-karya arsitektur sampai karya seni dijaga dan dirawat dengan baik.

\section{Pembahasan}

\section{Islam dan Jawa}

Islam merembes dan berkembang pesat di tanah Jawa pada permulaan abad ke-13 M, dengan ditandai perkembangan dan pertumbuhan jalur perdagangan lokal dan internasional 
(asing). Para pedagang muslim sudah ada di sebagian Indonesia selama beberapa abad sebelum Islam menjadi agama yang mapan dalam masyarakat-masyarakat lokal di Nusantara. Para pedagang Muslim aktif berinteraksi dan memanfaatkan pelabuhan-pelabuhan di pesisir utara Jawa, seperti;Gresik, Demak dan Cirebon. Sebagai wujud pergumulan sosial-ekonomi dan keagamaan, hingga maka muncul Raden Patah di Demak hadir sebagai penguasa atau bangsawan yang menguasai Jawa dengan berbagai aktivitas dan transaksi ekonomi melalui dagang. 4

Pada sisi lain, tradisi keagamaan dan kepercayaan yang dibawa oleh Islam dengan menggunakan gagasan dan idiom-idiom lokal, bahkan Islam, sambil mengadakan dialog yang bermakna dengan realitas-realitas sosio-kultural dan politik pada tingkat lokal sehingga Islam, sepanjang perkembangannya di Indonesia, telah menjadi bagian integral dari sejarah politik negeri ini.

Konversi penduduk Indonesia ini mulai diperdebatkan oleh beberapa ilmuwan dan para sejarawan tidak seragam memahami sumber-sumber Islamisasi yang seringkali sangat tidak informative, ${ }^{5}$ dan berselisih pendapat tentang kapan masuknya Islam di Indonesia, ${ }^{6}$ sehingga ada yang menjelaskan bahwa masuknya Islam sudah dimulai sejak abad I Hijriyah (abad VII), XIII dan XIII. Kendati demikian Islam baru menunjukkan kegiatan yang efektif dan sangat subur pada abad ke-13 ditandai dengan kelahiran kerajaan-kerajaan Islam di Sumatera (sejak berdirinya kerajaan Pasai) hingga kerajaan Perlak dan Demak (di Jawa).

Menurut MC.Ricklefs nusantara sejak periode tahun \pm 1300 telah menjadi sebuah unit Sejarah Indonesia Modern yang utuh dan padu,7 dengan menyebutkan tiga unsur fundamental yang memberikan kesatuan historis terhadap periode ini, antara lain;

Pertama adalah unsur kebudayaan dan agama: islamisasi Indonesia yang dimulai tahun \pm 1300 dan berlanjut hingga hari ini. Kedua adalah unsur topik saling pengaruh antara orang Indonesia dan orang Barat yang dimulai tahun \pm 1500 dan masih berlanjut. Ketiga adalah historiografi: sumber-sumber primer sepanjang periode ini ditulis hampir secara eksklusif dalam bahasa-bahasa Indonesia modern (Jawa dan Melayu, bukannya Jawa Kuno atau Melayu Kuno) dan dalam bahasa-bahasa Eropa. Antara tahun 1000 sampai \pm 1500 , unsur-unsur ini muncul dan terus ada.Bahkan masih terdapat perbedaan konseptual di kalangan ahli sejarah berupa pencampuradukkan antara "kedatangan Islam", "berkembangnya Islam", dan munculnya "kerajaan-kerajaan Islam" di pulau-pulau, misalnya; Jawa, Sumatera, Kalimantan, Sulawesi, Maluku, Sumbawa dan Madura. Beberapa di antaranya adalah benar-benar baru, yaitu warisanwarisan yang bersemangatkan Islam, tetapi sebagian besarnya mempunyai akar yang kuat pada kebudayaan pra-Islam.

Warisan budaya ini dianggap klasik dalam arti bahwa warisan Islam tersebut menetapkan norma-norma budaya yang otoritatif dan kerangka-kerangka makna bagi peradaban Indonesia sebelum abad XX. ${ }^{8}$ Sebagai model cara mendekatkan diri dengan Tuhan diwujudkan dala akulturasi Islam dan Jawa yang terlihat dalam beberapa bentuk perilaku budaya Jawa. ${ }^{9}$

Pada akhir abad ke-13 M, seiring dengan kemunduran Majapahit, secara praktis beberapa wilayah kekuasaannya mulai memisahkan diri dalam berbagai kadipaten-kadipaten menjadi pewaris dan saling mengklaim sebagai pewaris tahta Majapahit. Kesultanan Demak atau Kerajaan Demak adalah kerajaan Islam pertama dan terbesar di pantai utara Jawa ("Pasisir"). Demak sebelumnya merupakan kadipaten dari kerajaan Majapahit, kemudian muncul sebagai kekuatan 
baru mewarisi legitimasi dari kebesaran Majapahit. Sedangkan para wali (Walisongo) memanfaatkan kesenian sebagai alat dakwah yang sangat penting di dalam mensosialisasikan agama Islam di Jawa dengan memasukkan Unsur dan nilai-wayang nilai ke-Islaman dalam ceritera wayang. Kerajaan Demak menjadi pelopor penyebaran agama Islam di pulau Jawa dan Indonesia pada umumnya. meskipun usia Kesultanan Demak tidak berumur panjang dan segera mengalami kemunduran karena terjadi perebutan kekuasaan di antara kerabat dan para elite kerajaan. ${ }^{10}$

\section{Kerajaan Mataram-Islam}

Pada tahun 1560, kekuasaan Demak beralih ke Kerajaan Pajang yang didirikan oleh Jaka Tingkir/Hadiwijaya. Kerajaan Pajang terus mengadakan ekspansi ke Jawa Timur dan juga terlibat konflik keluarga dengan Arya Penangsang dari Kadipaten Jipang Panolan. Setelah berhasil menaklukkan Aryo Penangsang, Sultan Hadiwijaya raja Pajang (1550-1582), memberikan hadiah kepada Ki Ageng Penjawi dan Ki Ageng Pemanahan yang dianggap berjasa dalam penaklukan, Arya Penangsang. Ki Ageng Pemanahan dan Ki Penjawi. Ki Ageng Pemanahan memperoleh tanah di Hutan Mentaok dan Ki Penjawi memperoleh tanah di Pati.

Ki Ageng Pemanahan 1558-1575 berhasil membangun Hutan Mentaok itu menjadi desa yang makmur, bahkan lama-kelamaan menjadi kerajaan kecil dan pusat pemerintahan berada di Mentaok, wilayah yang terletak di sebelah Timur Kota Yogyakarta Kotagede. Raja-raja MataramIslam sadar akan tugasnya memasukkan unsur-unsur Islam dalam budaya Jawa dan mereka pun menyatakan legitimasi mereka juga sebagai raja-raja Islam dengan memakai gelar keagamaan Islam. ${ }^{11}$ Struktur kerajaan Mataram-Islam dalam pengembangan Islam dengan mendirikan Mahkamah Agung Islam dan ulama mendapat tempat sebagai Abdi dalem dalam urusan keagamaan, yang dikepalai oleh Penghulu. ${ }^{12}$ Selain itu Sultan Agung juga memberikan tanah perdikan kepada kaum ulama (kyai) yang mengasuh pondok pesantren, dalam rangka pengembangan Islam di tanah Mataram.

"Pesantren-pesantren desa dikembangkan di daerah-daerah Kabupaten, di samping itu juga oleh para ulama didirikan Pesantren Besar, pesantren takhasus (keahlian khusus) dan Perguruan Tariqat”. ${ }^{13}$

Ki Pemanahan meninggal pada tahun 1575 digantikan putranya, Danang Sutawijaya (15751601), yang sering disebut Pangeran Ngabehi Loring Pasar. Sutawijaya kemudian berhasil memberontak pada Pajang. ${ }^{14}$ utawijaya mengangkat diri sebagai raja Mataram Islam dengan gelar Panembahan Senapati dan mewarisi wilayah Kerajaan Pajang. Pajang kemudian dijadikan salah satu wilayah bagian dari Mataram yang beribukota di Kotagede. Selama pemerintahannya boleh dikatakan terus-menerus berperang menundukkan bupati-bupati daerah. Kasultanan Demak, Panaraga, Pasuruan, Kediri, Surabaya, berturut-turut direbut dan Cirebon pun berada di bawah pengaruhnya.Beberapa kasus (Peristiwa dan prahara) di dalam dinasti Di Jawa Tengah MataramIslam 15

Senopati digantikan, Mas Jolang/ Prabu Hanyokrowati (1601-1613), lebih dikenal dengan sebutan Panembahan Seda Krapyak (Raja yang wafat di Krapyak). Setelah itu tahta beralih sebentar ke tangan putra keempat Mas Jolang yang bergelar Adipati Martoputro. Ternyata Adipati Martoputro menderita penyakit syaraf sehingga tahta beralih ke putra sulung Mas Jolang yang bernama Mas Rangsang yang bergelar Sultan Agung Hanyakrakusuma (tahun 1613-1645). Di 
bawah Sultan Agung Mataram mengalami masa kejayaan. Ibukota kerajaan Kotagede dipindahkan ke Keraton Plered. Sultan Agung merupakan raja yang menyadari pentingnya kesatuan di seluruh tanah Jawa. Daerah pesisir seperti Surabaya dan Madura ditaklukkan supaya kelak tidak membahayakan kedudukan Mataram. Ia pun merupakan penguasa lokal pertama yang secara besar-besaran dan teratur mengadakan peperangan dengan Belanda yang hadir lewat kongsi dagang VOC (Vereenigde Oost Indische Compagnie). Kekuasaan Mataram pada waktu itu meliputi hampir seluruh Jawa, dari Pasuruan sampai Cirebon.

Sultan Agung mencurahkan perhatiannya pada bidang ekonomi dan kebudayaan. Upayanya antara lain memindahkan penduduk Jawa Tengah ke Kerawang, Jawa Barat, di mana terdapat sawah dan ladang yang luas serta subur. Sultan Agung juga berusaha mengakulturasikan unsurunsur kebudayaan Indonesia asli dengan Hindu dan Islam. Misalnya Garebeg disesuaikan dengan hari Malulud Nabi Muhammad SAW, hari raya Idul Fitri dan hariraya Idul Adha. Sejak itu dikenal Garebeg Mulud, Garebeg Puasa dan Garebeg Besar.. Pembuatan tahun Jawa ${ }^{16}$ dan kitab filsafat Sastra Gendhing merupakan karya Sultan Agung yang lainnya.

Pada masa Sultan Agung perdagangan semakin melemah, pelayaran dan pusat perdagangan pelabuhan menjadi mundur lantaran didominasi oleh Belanda. Pada tahun 1628-1629, Sultan Agung ingin menguasai Batavia, ia mengirim pasukan yang dipimpin oleh Baureksa dan dibantu oleh Adipati Ukur serta Suro Agul-Agul, namun usaha itu gagal. Sultan Agung wafat pada tahun 1645 dan dimakamkan di Imogiri, ${ }^{17}$ di wilayah pedalaman Jawa Tengah. ${ }^{18}$

Pasca Sultan Agung dengan anaknya Amangkurat I dengan pemberontakan dan korban ribuan ilmuan dan rakyat yang tidak berdosa. Pada Tahun 1755 Mataram-Islam pecah menjadi dua Kerajaan, yakni Kasultanan Yogyakarta dengan Raja Mangkubumi (Hamengku Buwono I) dan Kasunanan Surakarta dengan Raja Pakubuwono .

\section{Kasultanan Yogyakarta dan Belanda}

Kasultanan Yogyakarta merupakan salah satu pelanjut pewaris dan mata rantai kerajaan Mataram-Islam memiliki posisi, kedudukan strategis dan ujung tombak dalam mengembangkan dan mempertahankan agama Islam di Pulau Jawa, terutama Jawa bagian Selatan (pedalaman Jawa). Namun, kedatangan kolonialisme bangsa-bangsa Eropa dan Jepang membuat beberapa kerajaan mengalami konflik internal, Nusantara lebih homogen dalam sistem politik dan pemerintahan. ${ }^{19}$

Sebagai gambaran adalah peran dan kontribusi para priyayi, khususnya Sultan HB IX yang mempertahankan agama Islam dalam jiwa mereka pada masa kolonial Belanda. ${ }^{20}$ Adanya Relasi Islam dan Keraton Jawa (Kasultanan Yogyakarta), adalah "syntum' tata nilai kehidupan kebudayaan Indonesia. Relasi antara Islam dan Keraton ini terwujud pada pandangan, pola hidup dan mental-spiritual. Islam sebagai simbol kebudayaan dan nilai-nilai ketuhanan menyatu dalam ruang batin masyarakat Jawa dan Keraton, yang tersosialisasi dalam produk kebudayaan di dalam Keraton maupun di luar Keraton.

HB IX -X menyandang gelar Sultan yang mengandung pengertian dan makna, sebagai penguasa yang selalu menunaikan kwajiban untuk ingat kepada Tuhan Yang Maha Esa. ${ }^{21}$ Kewajiban vertikal dan horisontal ini tersandang dalam Gelar Sultan sebagai Kalifatullah Sayyidin Panatagama. $^{22}$ Di mana di dalamnya terkandung dimensi kerakyatan dan dimensi relegius 
(spiritual). Keseimbangan antara hablu min Allah dan hablu min al-nas, inilah yang tertuang dalam gelar Sultan. Di samping memiliki tanggungjawab duniawi, juga mempunyai tanggungjawab ukhrawi. Petunjuk-petunjuk ke arah kebaikan, sesuai dengan konsep Islam, ini secara keseluruhan terdapat dalam tata kehidupan dan tata bangunan di keraton Ngayogyakarta. ${ }^{23}$

Begitu juga gelar Sultan Agung dan HB IX yang dipakai "Sayidin Panata Gama" mengisyaratkan kedalamannya dan tanggung jawab kepada agama Islam, ${ }^{24}$ Sultan Agung dan Sri Sultan HB IX digambarkan sebagai sosok pribadi yang dapat merefleksikan sikap dan perilaku para nabi yang nota bene sebagai pribadi yang suci penuh nilai kebijaksaan; yang terpancar dalam perilakunya sepanjang masa. Sultan Agung digambarkan sebagai sosok pribadi yang dapat merefleksikan sikap dan perilaku para nabi yang nota bene sebagai pribadi yang suci penuh nilai kebijaksaan; yang terpancar dalam perilakunya sepanjang masa. Gelar "Sultan" yang disandang oleh Sultan Agung dan HB IX menunjukkan kapabilitas yang mumpuni dalam menata sistem pemerintahan yang damai (gemah ripah loh jinawe karta raharja), di masa Mataram-Islam. ${ }^{25}$

HB IX dengan Tahta untuk Rakyat-nya berarti segala kewenangan dan kekuasaan raja semata-mata diabdikan demi keselamatan, kesejahteraan, kemakmuran dan ketentraman rakyat. Sultan Hamengku Buwono IX mendapat amanah sebagai pemimpin tradisional dan pemimpin formal senantiasa berbuat demi bangsa dan Negara, seorang pemimpin, dalam menggerakkan demokrasi, seharusnya disemangati gelar yang melekat dalam diri sultan HB IX. Sultan Hamengku Buwono IX adalah salah satu figur pemimpin yang bisa mewujudkan falsafah kekuasaan itu, ketika ia tak hanya masih menjadi raja Keraton Yogyakarta, tetapi juga saat dalam pemerintahan nasional, termasuk menjadi wakil Presiden. ${ }^{26}$

HB IX mempunyai cara dan strategi dalam mengembangkan masyarakat, yakni inisiatif dari bawah diberi kesempatan, didorong dan diberi kekuatan sehingga rakyat menyebutkan "derek kersa dalem" pada hakikatnya telah ditinggalkan dan diganti dengan prinsip kepemimpinan yang "ing ngarsa sung tulada, ingin madya mbangun karsa, tut wuri handayani" (di depan memberi teladan, di tengah mengembangkan prakarsa dan di belakang memberi dukungan). HB IX sangat memperhatikan nasib rakyatnya, seperti yang tercermin dalam kebijaksanaannya membiarkan rakyat mendirikan rumah-rumah mereka di tanah keraton secara magersari. Berbudi bawa leksana, ambeg adil para marta (menjunjung budi luhur dan sifat adilnya terhadap semua yang hidup, atau adil dan penuh kasih) dan njaga tata titi tentreming praja (menjaga keteraturan dan hidup rakyat) serta karta tuwin raharja (aman dan sejahtera). Al-Ghazali dalam "Nasihat alMulk". ${ }^{27}$

\section{Hamengku Buwono IX-X dan Muhammadiyah}

Manusia dalam bermasyarakat tidak terlepas dari norma agama dan norma hukum yang berlaku dalam meraih kemaslahatan bersama. ${ }^{28}$ Agama memang sangat potensial untuk mendukung masyarakat memiliki beberapa kemungkinan fungsi terhadap pembangunan. Pertama, merupakan sumber motivasi bagi pembangunan, yaitu faktor yang dapat mendorong dan menggugah manusia dan masyarakat untuk membangun. Kedua, agama merupakan sumber inspirasi bagi pembangunan, yaitu faktor yang dapat menyumbangkan nilai pembangunan. Ketiga, merupakan sumber evaluasi bagi pembangunan, yaitu bahwa agama dapat dijadikan sebagai alat ukur dan kritik untuk kebaikan proses pembangunan. ${ }^{29}$ 
Dalam berbagai teori tentang pembentukan negara, negara merupakan lembaga politik yang sifatnya instrumental untuk mewujudkan cita-cita bersama: kebaikan dan kesejahteraan (dalam pemikiran politik Islam sa'adah al-darain, kebahagiaan di dunia dan di akhirat). Pemimpin (imam) bisa diangkat melalui dua cara; ahl al-hal dan wilayah al-'Ahad dipandang mirip dengan sistem kerajaan. Bung Karno, ketika meminta Sultan HB IX membantu mengawasi peranan aparatur negara.Masyarakat awam sama sekali tidak mempunyai bayangan tentang fungsi dan peranan yang dimainkan oleh badan pengawas keuangan negara tertinggi (supreme audit institution), yang terlepas dari pengaruh dan kekuasaan negara. Peranan BPK agaknya "misterius" ketika itu dan kurang mendapat porsi publikasi pers sehingga citranya di mata masyarakat luas hampir tidak dikenal dan dihargai. BPK berfungsi untuk mencegah penyelewengan keuangan negara.

Figur Sultan HB IX ternyata menampilkan peranan sebagai sumber modal dan asset social. Bila panggung politik nasional awal demokrasi terpimpin diibaratkan dengan kelompok elite bermain kartu, maka Sultan HB IX memiliki beberapa kartu truf, yang dapat mewujudkan skenario permainan politik tinggi yang dibayangkan oleh Bung Karno. Kartu-pertama, Sultan HB IX adalah tokoh sipil terkemuka dengan pengaruh yang luas di dalam birokrasi sipil, dengan salah satu pusat rekayasa birokrasi sipil, yaitu Yogyakarta dengan Universitas Gadjah Mada (pusat pencetakan tenaga-tenaga profesional di bidang administrasi negara). Kartu kedua, Sultan HB IX adalah tokoh sipil yang mempunyai pengaruh yang luas dalam tubuh angkatan bersenjata. HB IX beberapa kali menjabat Menteri Pertahanan. Angkatan Bersenjata membutuhkan Sultan HB IX untuk mewujudkan skenario pertahanan rakyat semesta di mana terjadi proses sinergi nasional antara kekuatan angkatan bersenjata, yang masih terbatas pemilihan teknologi dan mesin perang, serta kekuatan moral masyarakat sipil, yang sudah terbukti ketika mengalami situasi perang mempertahan Kemerdekaan. ${ }^{30}$

Al-Anshari menjelaskan bahwa yang dimaksud dengan wilayah al-'Ahad adalah wasiat khalifah atau imam setelahnya. ${ }^{31}$ Pandangan Sultan HB IX terhadap agama dan hubungan antaragama, maka berikut ini akan dipaparkan terlebih dahulu beberapa sikap teologi yang biasanya menonjol dalam kenyataan kehidupan beragama. John Hick menyebut adanya tiga sikap teologi agama-agama, yaitu; ekslusif, insklusif dan pluralis. ${ }^{32}$

Letak daya tarik kepemimpinan Sultan HB IX. Sebagai raja dengan latar belakang pendidikan Barat yang bersifat rasional dan progresif, ia mampu dan berhasil memadukan antara hal-hal yang bersifat supra-natural di satu sisi dan yang rasional di sisi lain. Manusia adalah makhluk yang mengenal simbol (homo simbolicus) dan kepemilikan manusia akan simbol itu meru-pakan ciri yang membedakan manusia dari hewan (Cassirer, 1987:40). Manusia berpikir, berperasaan, dan bersikap dengan ungkapan-ungkapan yang simbolis. Manusia tidak pernah melihat, menemukan, dan mengenal dunia secara langsung, tetapi melalui simbol. 33

HB IX memiliki jaringan pergaulan luas dengan tokoh-tokoh tingkat nasional dan lokal. Di tingkat nasional, HB IX bergaul erat dengan tokoh-tokoh Islam, seperti Dr. Moh. Natsir, Mr. Muhammad Roem, Ki Bagus Hadikusumo, bahkan HB IX menjadi wakil Perdana Mentri pada saat Kabinet M. Natsir. ${ }^{44}$ Sementara putra-putra HB IX di Yogyakarta, misalnya, Pangeran Mangkubumi (kini HB X) memiliki hubungan yang erat dengan Muhammadiyah,35 Universitas 
Islam Indonesia, Universitas Muhammadiyah, Masjid Syuhada dan Ikatan Persaudaraan Haji Indonesia Cabang Yogyakarta.

Hamengku Buwono (HB) IX memiliki tempat istimewa di tengah masyarakat Yogyakarta. Ia mudah membaurkan diri dengan rakyat, masyarakat dan berbagai lapisan rakyat amat dicintainya. Pada waktu luang HB IX tidak segan-segan---menyusup ke tengah-tengah kesibukan orang kecil, miskin, dan pedesaan---termasuk masyarakat Islam (santri). ${ }^{6}$ Sultan HB IX (1912-1988), memiliki kesan-kesan yang menarik dan impresif terhadap kreativitas dan kontribusi amal sosial Muhammadiyah.37 HB IX pernah mengatakan bahwa Rakyat dan negara sangat tahu bahwa Muhammadiyah selalu dapat dikemudikan dengan stabil dan telah menunjukkan pula kesanggupan, keuletan dan ketabahannya dalam melaksanakan perjuangan untuk mencapai citacitanya yang luhur dan muliai bagi martabat manusia Indonesia:

"Muhammadiyah telah membuktikan lulus dari ujian-ujian zaman, baik selama penjajahan; Belanda, Jepang dan masa-masa sulit yang dialami oleh Republik Indonesia. Muhammadiyah dapat menjadi contoh bagi organisasi-organisasi sosial lainnya."38

Pergeseran politik dan pemikiran keagamaan Arab dan Turki Usmani (1290-1922) telah memunculkan faktor baru dalam kesetaraan keagamaan Jawa.39 Mitos-mitos religio-politik Mataram diterima sebagai fakta sejarah, dan banyak orang Jawa Yogyakarta yang tidak tergoyahkan loyalitasnya kepada dinasti itu dan di atas segala-galanya terhadap Sultan HB IX, yang mereka yakini sebagai seorang Kalipatullah sejati dan Panatagama. Muhammadiyah40 sebagai gerakan sosial-keagamaan ini lahir dari lingkungan budaya perkotaan, Kauman, simbol jantung kota Yogyakarta, yakni di sekitar lingkungan keraton Yogyakarta. Ahmad Dahlan, pendiri Muhammadiyah, adalah putra seorang khatib masjid sultani. Karena itu, semasa kecilnya ia telah mengenyam pendidikan sekolah model Barat yang didirikan oleh pemerintah kolonial Belanda.Ia berkesempatan menamatkan pendidikan agama sambil bermukim dan belajar di MakkahMadinah. ${ }^{41}$

Progresif gerakan Muhammadiyah yang tidak hanya berkiblat ke Mesir, (Timur Tengah) melainkan juga menyerap unsur-unsur Jawa dan budaya Barat yang positif (manajemen) dan Muhammadiyah bersifat dinamis, tanggap terhadap budaya Barat, dan karena Muhammadiyah tidak dibebani oleh warisan budaya kejawen, maupun warisan budaya pesantrenan. ${ }^{42}$ Langkah yang ditempuh Muhammadiyah bertumpu pada upaya mencerahkan umat Islam agar mampu menguasai ilmu dan teknologi sesuai dengan tantangan dan kemajuan zaman.

\section{Santrinisasi Priyayi}

Fenomena kedekatan keraton Kasultanan Yogyakarta dengan Islam, justru membuat budaya Jawa makin tumbuh dan berkembang di berbagai wilayah pedesaan, khususnya di desa-desa santri maupun abangan. Pada masa Sultan Hamengku Buwono (HB) X dan Sri Paku Alam VIII (Paku Alam IX) inilah tradisi membaca Al-Quran hingga khatam bersama-sama (semakan/tadarusan) dijadikan bagian dari rangkaian upacara memperingati ulang tahun Keraton Yogyakarta.

Sementara di sisi lain, wajah santri Daerah Istimewa Yogyakarta menjadi lebih lengkap sejak keberangkatan Sri Paku Alam VIII-orang kedua terpenting di Kesultanan Yogyakartamenunaikan ibadah haji bersama hampir seluruh keluarganya pada 1998. Yang selama ini, 
masyarakat umum mengenal mitos larangan bagi Raja Jawa melaksanakan ibadah Haji. Mitos seperti ini sebenarnya bisa dianggap telah badar ketika Sri Sultan Hamengku Buwono X, pergi menunaikan ibadah Haji di masa awal ia naik tahta.43 Sultan Hamengku Buwono X, adalah seorang Haji yang aktif dalam berbagai kegiatan keislaman. 44

HB X menikahkan anak-anaknya sendiri (perempuan dengan suaminya) dan penghulu hanya bertugas mencatat pernikahan tersebut secara formal dan resmi tercatat di kantor Urusan agama (KUA). Bahkan di lingkungan kerajaan ada abdi dalem berpakaian jilbab (selama ini terkesan hanya kemben), ada suara tembang macapat diiringi gending-gending Jawa. 45

Jika diurutkan sebagai sebuah narasi kehidupan manusia dari lahir sampai dimasukkan ke liyang kubur, mengandung makna dan perlambang permohonan, seperti; Sastra Gending. ${ }^{46}$ Misalnya; tembang Mijil (seorang jabang/biji), Sinom (enom/ anak muda), Dhandhang Gula (gula manis), Maskumambang (keprihatinan), Kinanthi (Kemesraan), Asmaradana (jatuh cinta), Gambuh (sikap angkuh), Durma (firasat buruk), Pangkur (menjauhi duniawi, membelakangi dan aktif dalam kerohanian dan asketis), Megatruh (pisahnya jiwa dengan badan), Pocung gambaran orang yang sudah meninggal dan dikafani jasadnya dan Wirangong (jasad/fisik yang sudah pisah dengan ruh dimasukkan ke liyang kubur).

Dalam ibadah sunnah, misalnya, bisa dilihat pada acara-acara aqiqah, sunatan, perkawinan dan upacara-upacara kematian, terutama acara ular-ular (sambutan berisi nasihat untuk kedua mempelai maupun masyarakat yang hadir dalam kedua acara tersebut) dengan menggunakan bahasa Jawa dan biasanya, yang memberi sambutan tersebut adalah ustad (kiai) dan tokoh masyarakat yang pada umumnya mampu menggunakan bahasa Jawa baik ngoko (kasar), kromo madya maupun kromo inggil (halus), lantaran mereka mengkaji kitab-kitab kuning dalam bahasa Jawa. Fenomena dan dinamika tersebut dapat dipahami dengan baik apabila sejak awal kita telah memosisikan Raja Jawa sebagai orang Islam dan bukan sebagai bagian dari suatu kelompok yang bertentangan dengan kalangan santri, sekalipun kedua raja tersebut tentu saja tergolong priyayi dalam terminologi Geertz. Jadi betapa pun jauhnya seorang Jawa dari ajaran agama dan karena itu dikategorikan sebagai priyayi ataupun abangan, tetapi akar kulturalnya menjadi daya panggil yang kuat untuk tumbuh dan berkembang sebagai seorang yang lebih sungguh-sungguh dalam mengamalkan ajaran Islam. 47

Proses santrinisasi ini telah berlangsung sejak lama, tetapi perkembangan yang paling mengesankan memang berlangsung sejak satu dan dua dasawarsa terakhir ini, yakni; pada masa yang diakui atau tidak, kebetulan berada di bawah kepemimpinan Orde Baru (Presiden Soeharto). Meski banyak akibat negatif yang ditinggalkannya, haruslah diakui bahwa dalam dua periode ini telah terjadi santrinisasi yang luas. Akibatnya, kini, orang tidak lagi bicara dikotomi santri dan abangan, karena semua menjadi relatif tersantrikan. 48

Menurut Taufik Abdullah Islamisasi di Jawa ditandai perkembangan ke arah pembentukan corak "tradisi dialog", yang berbeda dengan dunia Melayu yang memperlihatkan corak "tradisi integratif", di mana Islam diterima menjadi bagian yang inheren dari pembentukan sistem budaya.49 Proses santrinisasi dapat dipastikan jawabnya adalah lantaran mereka ingin mengamalkan ajaran agamanya secara lebih sungguh-sungguh atau lebih tepat santrinisasi karena pada dasarnya mereka sudah Islam..$^{0}$ 
Keraton-keraton secara resmi memeluk Islam, gaya kehidupan pengaruh tradisi Hindu-Jawa masih tetap menonjol. Pertunjukan wayang, gamelan sebagai instrumennya, terutama pada harihari besar peringatan Islam (Maulud, Rajaban dan Isra Mikraj), yang merupakan ritual keagamaan, masih berbentuk Hindu-Budha dengan isinya bernuansa Islam bahkan dipraktikkan oleh mereka yang telah menjalankan shariah dengan setia. Acara ulang tahun kerajaan diwarnai dengan kegiatan-kegiatan keagamaan Islam sebagai arena untuk memahami berbagai peristiwa kehidupan sehari-hari mereka, ${ }^{1}$ telah memberikan warna baru dan perubahan dalam beberapa aspek kehidupan masyarakat, baik kehidupan rohani maupun jasmani, $5^{2}$ yang kemudian muncul adalah masjid-masjid, makam-makam di atas bukit,53 keraton-keraton dan taman-taman. Bangunan-bangunan baru yang dipengaruhi dan didirikan Islam secara fisik tidak jauh berbeda dengan bangunan tempat ibadah masa sebelumnya.

Manusia untuk selamat lahir batin di dunia hingga akherat, hendaknya mengenali dan mengendalikan keberadaan empat hal (Mutmainah, Supiah, Amanah, dan Luamah) menguasai tubuh manusia. Pengendalian diri dengan bersenjatakan rendah hati akan menyebabkan sehat mental, sehat emosi, sehat fisik, dan sehat spiritual, sehingga sehat pula akal budinya. Namun jika tanpa pengendalian diri akan mengakibatkan sering sedih hati, sakit hati, kecewa, dan sering mengurung diri. Bekal hidup yang tertuang dalam HB IX. Ajaran "Sastra Gending" (menggambarkan rasa "tidak ada sastra tanpa gending dan tidak ada.

\section{Simpulan}

Kepemimpinan seseoarang tidak pernah lepas dari nilai spiritualitas dan sosial. seorang pemimpin politik dan negarawan dapat dilihat dari kebijakan dan keputusan yang sedikit banyak memiliki kualitas dan moralitas. Dalam era post modern sekarang, perbicangan tentang spiritualitas mendapat apresiasi yang sangat tinggi.

Pengamalan ibadah Islam dengan ritual-lokal,54 juga dalam hal cara berpakaian jilbab dan berbicara dengan kosa kata Arab, seperti; Insya Allah, alhamdulillah dan subhanallah. Selanjutnya idiom-idiom Arab ini mulai mengisi pelbagai pembicaraan di keraton dan masyarakat Jawa. Kata-kata; taufiq, hidayah, shalihah, sakinah, mawaddah, rahmah dan barkah, telah menjadi kosa kata yang amat popular dalam pergaulan sehari-hari di Jawa, mengalahkan kata-kata dalam bahasa Jawa, seperti: sugeng rawuh, tut wuri handayani dan menang tanpo ngasorake.

Fenomena kedekatan keraton Kasultanan Yogyakarta dengan Islam, justru membuat budaya Jawa makin tumbuh dan berkembang di berbagai wilayah pedesaan, khususnya di desadesa santri maupun abangan. Hal itu, bisa dilihat pada acara-acara aqiqah, sunatan, perkawinan dan upacara-upacara kematian, terutama acara ular-ular (sambutan berisi nasihat untuk kedua mempelai maupun masyarakat yang hadir dalam kedua acara tersebut) dengan menggunakan bahasa Jawa dan biasanya, yang memberi sambutan tersebut adalah ustad (kiai) dan tokoh masyarakat yang pada umumnya mampu menggunakan bahasa Jawa baik ngoko (kasar), kromo madya maupun kromo inggil (halus), lantaran mereka mengkaji kitab-kitab kuning dalam bahasa Jawa dengan berbgai idiom-idiomnya.

\section{Catatan Kaki}

${ }^{1}$ Sambutan Presiden Jokowi pada penutupan Festival Keraton Nusantara ke XII di Taman Gua Sunyaragi, Kota Cirebon, Provinsi Jawa Barat, Senin 18 September 2017 
2 Pemberian keris Jaka Piturun adalah tanda ahli waris takhta. Tetapi, hal itu tidak dilakukan HB IX pada HB X. Penobatan KGPH Herjuno Darpito (HB X), merupakan hasil musyawarah internal. Yang terdiri atas adik-adik kandung, sedherek dalem (adik lain ibu), dan sentana dalem (paman, bibi, dan sepupu, pen).

3 Sebelum menjadi Negara Republik Kesatuan Republik Indonesia (NKRI), zaman dahulu Indonesi memiliki banyak sekali kerajaan yang pemerintahan dipimpin oleh Raja.Puluhan Kerajaan di Nusantara mengadakan Festival Keraton se-Jawa di Solo pada tahun 1992, kegiatan ini kemudian dikembangkan menjadi Festival Keraton Nusantara (FKN). Festival Keraton Nusantara digelar pertama kali pada tahun 1995 di Yogyakarta dengan diikuti 20 utusan keraton/istana dari beberapa kerajaan yang ada di Indonesia.

4J.C.Van Leur, Indonesian Trade and Society (Den Haag:Van Hoeve,1955), h.134.

5Rachmat Taufiq Hidayat, dkk, Almanak Islam, h.341

${ }^{6}$ Nurcholish Madjid, Islam Doktrin dan Peradaban Sebuah Telaah Kritis Tentang Masalah Keimanan, Kemanusiaan dan Kemodernan (Jakarta: Paramadina, 1995), h.V-VII.

7M.C.Ricklefs, Sejarah Indonesia Modern 1200-2004,terj.(Yogyakarta: Serambi, 2007), h. 27

${ }^{8}$ M.C.Ricklefs,Sejarah Indonesia Modern (Yogyakarta:Serambi,2007), h.115

9Sinkretisme yang diwujudkan antara lain dalam bentuk tradisi slametan, tahlilan, yasinan, ziarah, mistik, tedun, wayangan, golek dina, sesaji, ngalap berkah dan mencari dukun dari dahulu hingga sekarang tidak sama. Orang sekarang mengetahui tradisi, seperti: slametan, tahlilan, yasinan, ziarah, mistik, tedun, wayangan, golek dina, sesaji, ngalap berkah dan mencari dukun tersebut telah turun menurun serta mengalami berbagai tahap perubahan. Sutiyono, Benturan Budaya Islam: Puritan dan Sinkretis, (Jakarta: PT Kompas Media Nusantara, 2010), h.5. Di Jawa Islam tampil sebagai alternatif, untuk kemudian menjadikan pengganti kekuasaan yang ada. Jadi yang tampil ialah sesuatu dilema kultural dari orang baru di dalam bangunan politik yang lama, dalam Taufik Abdullah dan Sharon Shiddique (Ed.), Tradisi dan Kebangkitan Islam di Asia Tenggara (Jakarta: LP3ES, 1988), h.75.

${ }^{10}$ Bukti dari peninggalan bersejarah Demak ialah Mesjid Agung Demak, yang menurut tradisi didirikan oleh Wali Songo. Pada masa raja ke-4 (Sunan Prawoto), keraton dipindahkan ke Prawata (dibaca "Prawoto") dan untuk periode ini kerajaan disebut Demak Prawata. Sepeninggal Sunan Prawoto, Arya Penangsang memerintah kesultanan yang sudah lemah ini dari Jipang-Panolan (sekarang dekat Cepu). Kotaraja Demak dipindahkan ke Jipang dan untuk priode ini dikenal dengan sebutan Demak Jipang.

11Adaby Darban, Sultan Agung Hanyakrakusuma memakai gelar spiritual-keagamaan; Ngabdurahman menyebutkan.... Sayidin Panatagama Khalifatullah ing tanah Jawa (Hamba Pengasih yang mengatur agama wakil Tuhan di tanah Jawa).

12 Adapun ulama yang masuk dalam lingkungan birokrat kerajaan Islam Mataram diberi gelar; Penghulu, Ketib, Modin, Kaum, dan Abdi Dalem Kaji. Lebih lanjut, Z. A. Nuh, Peradilan tinggi Islam

13 Sri Sutjiatiningsih dan Sutrisno Kutoyo (Ed.), Sejarah Pendidikan Daerah Istimewa Yogyakarta, (Jakarta: Proyek IDKP Dep P dan K 1980/1981), 29 .

14Pemanahan berhasil membangun Hutan Mentaok itu menjadi desa yang makmur, bahkan lamakelamaan menjadi kerajaan kecil dan pusat pemerintahan berada di Mentaok, wilayah yang terletak di sebelah Timur Kota Yogyakarta dan selatan Bandar Udara Adisucipto sekarang. Danang Sutawijaya (15751601), yang juga sering disebut Pangeran Ngabehi Loring Pasar. Sutawijaya kemudian berhasil memberontak pada Pajang.

15 Kerajaan Mataram pada masa keemasannya pernah menyatukan tanah Jawa dan sekitarnya, termasuk Madura. Negeri ini pernah memerangi VOC di Batavia untuk mencegah semakin berkuasanya firma dagang itu, namun ironisnya malah harus menerima bantuan VOC pada masa-masa akhir menjelang keruntuhannya. Mataram merupakan kerajaan berbasis agraris/pertanian dan relatif lemah secara maritim. Ia meninggalkan beberapa jejak sejarah yang dapat dilihat hingga kini, seperti kampung Matraman di Batavia/Jakarta, sistem persawahan di Pantura Jawa Barat, penggunaan hanacaraka dalam literatur bahasa Sunda, politik feodal di Pasundan, dan beberapa batas administrasi wilayah yang masih berlaku hingga sekarang (pen).

${ }^{16}$ Sultan Agung merubah tahun Saka yang bersandar atas peredaran Matahari (Syamsiyah) diubah dengan Hijriyah yang bersandar pada peredaran bulan (Qomariyah), namun cara menghitungnya tetap dari tahun Saka. Perhitungan hari dipergunakan hari-hari Islam (Isnain, Salasa, Raba, Khomis, Jumat, Sabtu dan Ahad) dan digabungkan dengan hari pasaran Jawa lima hari (Wage, Kliwon, Legi, Pahing dan Pon). Perhitungan bulan dipakai bulan-bulan Islam (Sura, Sapar, Maulud, Jumadil awal dan Syawal) akan tetapi bulan-bulan Jawa Lama tetap dipergunakan yang kemudian disebut dengan mangsa, yang lamanya tidak 
tetap (ada yang kurang dari 20 hari tetapi ada yang lebih dari 30 hari).Demikian pula sistem perhitungan Windon (setiap 8 tahun), tetapi tetap dipakai dan nama-nama tahun dipergunakan huruf Arab (Alif, Ehe, Jumawal, Je., Dal, Be, Wawu dan Ji Makhir).

${ }_{17}$ Mataram adalah daerah yang menghasilkan dinasti-dinasti Jawa yang paling kuat dan paling lama. Mataram-Hindu abad VIII- XI dengan beberapa Candi, seperti, Candi Borobudur, Pawon dan Prambana. Mataram-Islam (1577-1775) dengan Tarikh Saka yang berdasarkan tahun matahari (1 tahun = 365 hari) menjadi tarikh Jawa-Islam yang berdasarkan tahun bulan ( 1 tahun= 354 hari), sesuai tarikh Islam. Tahun 1633 itu adalah tahun Saka 1555 dan tahun Saka ini menjadi tahun Jawa-Islam 1555 pula. Sultan Agung mengirim utusan ke Mekkah dan yang di tahun 1641 kembali dengan membawa para ahli agama untuk menjadi penasehat Karaton dan memperoleh gelar Sultan 'Abdul Muhammad Maulana Matarami. Perjanjian Giyanti Tahun 1755 membagi Mataram-Islam menjadi dua bagian, Kasunanan Surakarta (kini PB XIII dan Kasultanan HB X). Tahun 1812 Kasultanan Yogyakarta melepas Kadipaten Paku Alaman (1812-kini). Perjanjian Salatiga tahun 1757 membagi Kasuhunan menjadi dua. Kasuhunan Surakarta, dan Mangkunegara diperintah oleh Mas Said yang bergelar Pangeran Adipati Arya Mangkunegara.

18Dari kedua wilayah ini Daerah Pajang dan Mataram-Islam (lokasi kota Surakarta dan Yogyakarta sekarang) ini merupakan daerah-daerah pertanian yang sangat subur. Di mana wilayah ini sejak abad ke VII$\mathrm{X}$ yang menjadi pusat politik Kerajaan Mataram-Hindu dengan berbagai peninggalan candi besar maupun kecil, seperti; candi Borobudur, Pawon dan Prambanan. Namun, sejak abad X tidak lagi menjadi pusat sebuah kerajaan besar dan bahkan bergeser ke Jawa Timur, yakni Kerajaan Singosari dan Majapahit. Islamisasi kemudian berlangsung dalam komunitas-komunitas yang sebelumnya beragama Hindu-Budha di mana anak negeri suku bangsa Jawa berasal dan berkembang.

19 Beragam kerajaan merdeka "yang kecil jumlah penduduknya" memiliki sistem tersendiri, paling tidak secara budaya. Hal inilah yang disebut sebagai dinasti, saat mereka muncul sebagai ratu dan raja, walau sama sekali bukan aparatur pemerintahan. Kecuali di Yogyakarta (lalu Aceh, Jakarta, dan Papua), sistem pemerintahan lainnya hampir sama. Di beberapa daerah itulah dinasti politik berkuasa, walau dalam bentuk yang paling lunak, sebagai pengejewantahan perbedaan budaya. Daerah Istimewa Yogyakarta, yang diatur oleh UU Keistimewaan.

20 Denys Lombard, Nusa Jawa; Silang Budaya, Kajian Sejarah Terpadu; Batas-batas Pembaratan, (Jakarta: Gramedia Pustaka Utama, 1996), 103

21 Damardjati Supadjar dalam Kata Pengantar ter. Mark R Woodward "Kesalehan Normatif Versus Kebatinan Islam Jawa” (Yogyakarta: LKIS, 1998), XIX menjelaskan makna Gelar Sultan itu, merupakan laku agung, tekad menegakkan kebenaran, keindahan dan kebaikan. Lihat. Juga, Marsal G. Hodgson, The Venture of Islam Book Two: The Classical Civilization of the High Caliphate Atleticism spiritual of Islam (Chicago: University of Chicago, 1974), 10.

${ }^{22}$ Sayyidin Panata Gama Kalifatullah (Pemimpin yang mengatur masalah-masalah)

23 Mark R. Woodward juga menerangkan lebih detail tentang Tata Letak Bangunan Keraton, Alun-alun, Pasar, Tugu, Bangsal Kencana, terutama bab VI, Keraton Yogyakarta dan Struktur Jalan Mistik. Lihat, De Graaf .J. dan T.G.Pigeud, Kerajaan-kerajaan Islam di Jawa (Jakarta: Grafiti,1985), 80. Baik penelitipeneliti Barat maupun Indonesia, biasanya memang lebih memberikan perhatian pada pusat-pusat wacana (center of discourse). Dalam penelitian ini, penulis justru ingin membahas suatu naskah yang dalam istilah Jane Drakard dipandang sebagai naskah-naskah Melayu dari wilayah dan wacana pinggiran. Padahal suatu wacana baru terlihat kebesarannya bila diteropong dari seberapa jauh pengaruhnya terhadap wilayahwilayah pinggiran. Jane Drakard, Sejarah Raja-raja Barus: Dua Naskah dari Barus (Jakarta: EFEO, 1988), 14 .

24 M. Din Syamsuddin, Etika Agama dalam Membangun Masyarakat Madani (Jakarta: Logos Wacana Ilmu, 2000), $\mathrm{x}$.

25 Sudibyo, Babad Sultan Agung (Yogyakarta: Depdikbud, 1980), 24-26.

26 Tri Agung Kristanto, Keutamaan Seorang Pemimpin, dalam Sepanjang Hayat Bersama Rakyat, Julius Pour dan Nur Adji, Ed.( Jakarta: PT Kompas Media Nusantara, 2012), 182-3

27Petuah Para Raja) mengatakan bahwa Tuhan mengutus para Rasul dan membekali mereka dengan wahyu, dan mengutus para raja dan membekali mereka dengan farra-izadi, (Bahasa Persia, berarti "kekuatan Ilahi", kemenangan).Abu Hamid Al-Ghazali, Nasihat al-Mulk (Teheran: T.P. 1317 H), 9.

28 Munawir Sadzali, Islam Dan Tata Negara; Ajaran, Sejarah Dan Pemikiran (Jakarta: UI Press, 1980), 99.

29 M. Din Syamsuddin, Etika Agama dalam Membangun Masyarakat Madani (Jakarta: Logos Wacana Ilmu, 2000), 44 .

${ }^{\circ}$ HB IX begitu gigih dalam perundingan dengan Gubernur L. Adam.Frans Meak Parera. “Ketokohan HB IX Reformator Budaya dan Orde Baru”, Prisma Edisi Khusus 20 Tahun 1971-1991, 49. 
31 Abu Hasan 'Ali Ibn Muhammad al-Habib al-Bisri al-Bagdadi al-Mawardi, al-Ahkam alShultoniyah wa al-Wilayat al-Dinniyyah (Mesir: Mustafadalah Atsar dari Sahabat Rasulullah al-Babi alHalabi, 1973), 8. Abd. Hamid 'Ismail al-Anshari, Nidham al-Hukm fi al-Islam (Qatar : Dar al-Qathri ibn alFajaah, 1985), 136. Muhammad Dliya al-Din al-Ris, al-Nadhariyat al-Siyasiyah al-Islamiyah (Mesir; Dar alTurats, 1976), 235.

32 Sultan HB IX melarang berdirinya Gereja di wilayah keraton Kasultanan Yogyakarta, tetapi diizinkan Natal bersama di Sitihinggil, Ahmadiyah di Yogyakarta diberi kebebasan beragama dan mendirikan kegiatan sosial di bidang pendidikan dan keagamaan dari sekolah Taman Kanak-kanak (TK) sampai Perguruan Tinggi (PT). John Hick, A Christian Theology of Religions: the Rainbow of Faith (Louisville: Westminster John Press, 1995), 11-30.

33 Herusatoto, Simbolisme dalam Budaya Jawa (Yogyakarta: Hanindita, 2001), 9. Ahimsa Putra, Shri, "Struktur Simbolisme Budaya Jawa Kuno: Yang Meneng dan Yang Malih". Makalah dalam Sarasehan dan Pembinaan Budaya Jawa di Balai Kajian Sejarah dan Nilai Tradisional Yogyakarta, 4 Juni $1999,19$.

34 Mr. Muhammad Roem, Ki Bagus Hadikusumo, A.R. Baswedan, dan HB IX, pernah menjadi wakil Perdana Mentri pada saat Kabinet M. Natsir Arsip Nasional Republik Indonesia, Kabinet Negara Kesatuan 6 Oktober 1950-27 April 1951.

35 Hubungan itu sudah lama terjalin sejak HB VII, VIII dan ketika HB IX menjadi raja (1939-1988) Muhammadiyah dipimpin oleh Kyai Mas Mansur (1936-1942), Ki Bagus Hadikusumo (1942-1953), AR. Sutan Mansur (1953-1959), M.Yunus Anis (1959-1962), Ahmad Badawi (1962-1968), Faqih Usman (1968), dan A.R. Fachruddin (1968-1990). Kedekatan Hubungan Keraton-Muhammadiyah, nampak sekali dan Muhammadiyah memperoleh tanah wakaf/ pinjaman dari keluarga Keraton Yogyakarta dan sekolah-sekolah Muhammadiyah di wilayah keraton bisa berkembang pesat tidak lepas dari peran keraton Yogyakarta. Ki Bagus Hadi Kusumo, Perginya Seorang Raja Populis, dalam Sang Demokrat Hamengku Buwana IX, Dokumen Setelah Sri Sultan Mangkat 8 Oktober 1988.

${ }^{6}$ Raja yang baik adalah yang menjalankan keseimbangan antara kewenangannya dengan kwajiban yang besar. Ungkapan Jumbuhing Kawula Gusti (Persatuan Rakyat dan Raja) dipakai tidak hanya dalam mistik agama (persatuan antara Manusia dengan Tuhan), melainkan juga persatuan antara Rakyat dengan Raja. Raja harus memiliki kepribadian yang tanpa cacat dan keadilannya.Somarsaid Moertono, Negara dan Usaha Bina Negara di Jawa Masa Lampau (Jakarta: Yayasan Obor, 1985), 52-55.

37 Sultan HB IX menjadi raja (1939-1988) dan pada masa itu Muhammadiyah dipimpin oleh Kyai Mas Mansur (1936-1942) ahli agama, lulusan al-Azhar, Kairo dan berhasil merumuskan 12 tafsir langkah Muhammadiyah, Ki Bagus Hadikusumo (1942-1953) adalah profil yang terlibat dalam penyusunan Pembukaan UUD 1945 dan penyusun Mukaddimah Anggaran Dasar Muhammadiyah, AR. Sutan Mansur (1953-1959), M.Yunus Anis (1959-1962), Ahmad Badawi (1962-1968), Faqih Usman (1968, hanya beberapa saat karena meninggal dunia), A.R. Fachruddin (1968-1990) adalah ketua Muhammadiyah terlama dan paling jenaka di sepanjang sejarah Muhammadiyah (pen).

${ }^{8}$ A Munir Mulkhan, Pesan dan Kesan Ahmad Dahlan dalam Hikmah Muhammadiyah (Yogyakarta: 2007), 213-214.

39 R.A. Kern, "Penghulu", dalam Houtsma et.al. (Eds.), E.J Brill's First Encyyclopedia of Islam 1913-1936, Vol. VI (Leiden: E.J. Brill, 1987), 1024. Mitsuo Nakamura, The Crescent Arises over the Banyan Tree (Yogyakarta: Gadjah Mada University, 1993), 141.

40 Ahmad Dahlan selaku pendiri dan pemimpin Muhammadiyah awal, dilukiskan, seperti: Pertama tidak pernah menyimpang dari apa yang digariskan oleh adat dan tradisi istana dalam tingkah laku terhadap Sultan Yogyakarta. Peacock menggambarkan ini sebagai berikut: Kejadian kedua, yang juga diriwayatkan dalam "Tujuh Anekdot", menunjukkan bahwa, dalam bersikap, Dahlan tetap santun dan rendah hati terhadap pihak istana Yogyakarta. Dahlan ingin menyampaikan pada Raja, Paduka Sri Sultan, saran mengenai penyelenggaraan perayaan Garebeg. HB VII memiliki strategi agar Dahlan bisa "bicara bebas dan mengutarakan isi hatinya tanpa merasa silau dengan Paduka Sri Sultan dan para bangsawan di sekilingnya,". Raja menerima Dahlan di sebuah ruangan gelap pada malam hari. Meski penulis riwayat Dahlan menganggap kejadian itu mencerminkan keberanian Dahlan bicara kepada sang Raja, pembaca Barat lebih terkesan oleh kepatuhan dan kesopanan Dahlan. Dahlan di sini bukanlah Luther yang berteriak "Di sini aku berdiri" kepada pangeran. James L. Peacock, Purifying the Faith: The Muhammadiyah Movement in Indonesian Islam (Arizona: Arizona State University, 1992), 29.

${ }_{41}$ Taqiy al Din Ibn Taimiyah, Al-Syiyasah Al-Syar’iyah Fi> Ishlah Al-Ra'y Wal Al-Ra’uyah (Kairo: Da>r alKitab al-Arabiyah, 1989), 181. Solichin Salam menyebutkan KH Ahmad Dahlan: Tjita-tjita dan Perdjuangannja (Jakarta: Depot Pengadjaran Muhammadijah), 6. Abd. Hamid 'Ismail al-Anshari, Nidham al-Huk\} $\mathrm{m}$ fi $>$ al-Islam (Qatar: Da>r al-Qathri ibn al-Fajaah,1985), 136.

42 Alfian, Muhammadiyah: The Political Behavior of a Muslim Modernist Organization Under Dutch Colonialism (Yogyakarta: Gadjah University Press, 1989), 165; R H. Suja', Muhammadiyah dan Pendirinya (Yogyakarta: Pimpinan Pusat Muhammadiyah Majelis Pustaka, 1989), 18.

43 Abdul Munir Mulkhan, "Kekuasaan Kearifan Hidup Dan Moral Kekuasaan Kejawen," dalam Reinventing Indonesia Menemukan Kembali Masa Depan Bangsa, ed. Komaruddin Hidayat \& Putut Widjanarko (Bandung: Mizan, 2008), 744.

44 Sultan HB X sering hadir dalam kegiatan keislaman atau diwakili adiknya GBPH. Jayokusomo (aktif 
dalam organisasi keislaman, seperti; Persatuan Jamaah Haji Daerah Istimewa Yogyakarta, Pengurus Masjid Syuhada' dan Rumah Sakit Islam Yogyakarta. Kedua kakak-adik ini melanjutnya apa yang telah dilakukan oleh generasi sebelumnya (Sultan HB IX sebagai Raja (adik) dan GBPH. Prabuningrat(kakak) pernah menjadi Rektor Universitas Islam Indonesia (UII), Pengurus Masjid Syuhada, dan Ketua Persatuan Jamaah Haji Daerah Istimewa Yogyakarta.

45 Dalam tembang Macapat digambarkan kisi-kisi kehidupan manusia, nilai kearifan orang jawa yang yang sarat dengan nilai-nilai duniawi dan ukhrawi, dari lahir sampai ajal dan dimasukkan dalam liang kubur (dimakamkan), Sri Wintala Achmad,Wisdom Van Java Mendedah nilai-nilai Kearifan Jawa, (Bantul: In Azna Books, 2012), 15.

46 Sultan Agung, Serat Sastra Gending (Surakarta: Radya Pustaka, 1831), 1-7

47 M. Bambang Pranowo, "Revitalisasi Budaya," 713.

48 Kompas, Senin, 12 April 1999

49 Taufik Abdullah dalam Sharon Siddique (Ed.), Tradisi Kebangkitan Islam di Asia Tenggara (Jakarta: LP3ES, 1989), 58-99.

50 M. Bambang Pranowo, "Revitalisasi Budaya," 713.

${ }^{1}$ Lagu ilir-ilir (yang menggambarkan datangnya agama Islam di tanah Jawa dengan gambaran penekno blimbing kuwi (panjatkan pohon blimbing itu melambangkan perintah untuk mengerjakan lima rukun Islam), sluku-suku bathok (mengisyaratkan pentingnya ajaran prihatin dengan cara penyucian hati, jiwa, perut dan pikiran dengan ungkapan epistimologi berbahasa Arab Ghuslun-ghuslun Bathnaka (bersihkanlah perutmu/nafsumu) itu salah satu contoh orangtua Jawa menyuapi jiwa anak-anaknya dengan nafas spiritualisme. Simbol-simbol bahasa tersebut pada akhirnya menggambarkan bagaimana orang Jawa memahami dan menjalankan agamanya, Kejawen, Vol I, No. 2. Agustus 2006), 2-3.

$5^{2}$ Mark R. Woodward, Islam in Java: Normative Piety and Mysticism in the Sultanate of Yogyakarta (Tucson: The University of Arizona Press, 1989), 2.

53 Uka Tjandrasasmita, Penelitian Arkeologi Islam di Indonesia dari masa Ke Masa (Kudus: Menara Kudus, 2000), 72-73.

54 Doa-Doa Islami, seperti; Alamin diucapkan Ngalamin, Alaikum diucapkan Ngalaikum, Bismillah diucapkan Semilah, Muhammad diucapkan Mukamad, ini diperbolehkan atau sah. Sutiyono, Benturan Budaya, 5-6.

\section{DAFTAR PUSTAKA}

Amin M.Abdulllah, dalam Adat dan Islam Dalam Khazanah Budaya Keraton Yogyakarta (Yogyakarta: Yayasan Kebudayaan Islam Indonesia Bekerjasama dengan UIN Sunan Kalijaga Yogyakarta, 2007)

Atmakusumah (ed.), Tahta Untuk Rakyat, Celah-celah Kehidupan Sultan HB IX (Jakarta: Gramedia, 1982)

Anderson,Benedict, Kuasa Kata: Jelajah Budaya Politik Di Indonesia (Yogyakarta: Mata Bangsa, 2000)

Brackman, Arnold C., "Seorang Jawa yang Besar, Seorang Indonesia yang Besar", dalam Atmakusumah (peny.), Tahta Untuk Rakyat, Celah-celah Kehidupan Sultan HB IX (Jakarta: Gramedia, 1982)

Dwipayana, AAGN Ari, Sura Merdeka 14 Desember 2010.

Hans, Antlov, (Ed.). "Leadership on Java", terj. Kepemimpinan Jawa Perintah Halus, Pemerintah Otoriter (Jakarta: Yayasan Obor Indonesia, 2001),

Herlambang, Munadi , Tumbangnya Dinatisisme Negeri, Koran Sindo, o3 April 2013

Herusatoto,Budiono, Simbolisme dalam Budaya Jawa (Yogyakarta: Hanindita, 1987)

Istikhari Kr, Naufil, Runtuhnya Dinasti Bangkalan, JAWA POS, 05 Desember 2014

Mas,Marwan, Meruntuhkan Dinasti Korupsi,KORAN SINDO, 24 Desember 2013

Mahbubani,Kishore,Dinasti Kepemimpinan Negara-negara Asia,TEMPO, 11Januari 2013

Lendong, Romanus Ndau, Menangkal Dinasti Politik, MEDIA INDONESIA, 18 Januari 2017 
Murthado, Islam Jawa: Keluar dari kemelut Santri vs Abangan (Yogyakarta: Lappera Pustaka Umum, 2002).

Niels,Mulder, Kepribadian Jawa dan Pembangunan Nasional (Yogyakarta: UGM Press, 1986)

Piliang, Indra Jaya, Dinasti Politik dan Politik Dinasti,Koran Jakarta, 23 Oktober 2013

Paraera,F.M., "Ketokohan HB IX, Reformator Budaya dan Perintis Orde Baru,” Prisma (1988)

Purwadi, Sejarah Kanjeng Sultan Hamengku Buwono IX (Yogyakarta: Hanan Pustaka, 2006)

Rumawi, Ngarsa Dalem Dundum Warisan (Yogyakarta: LKIS, 2008)

Sartono Kartodirjo, A. Sudewa dan Suhardjo, Perkembangan Peradaban Priyayi (Yogyakarta:

Gajah Mada University, 1987)

Simuh, Sufisme Jawa Transformasi Tasawuf Islam Ke Mistik Jawa (Yogyakarta:Bentang Budaya, 1955), Cet. I.

Soemardjan,Selo, In Memoriam HB IX, Sultan of Yogyakarta 1912 - 1988, Cornell Southeast Asia Program, Indonesia Magazine, No. 47, April 1989

Sutrisno K. Sri Sultan HB IX Riwayat Hidup dan Perjuangan (Jakarta: Mutiara Sumber Ilmu, 1996)

Sudjito, Masyarakat Pedesaan (Yogyakarta: Tiara Wacana, 1992)

Sutrisno K. Sri Sultan HB IX Riwayat Hidup dan Perjuangan (Jakarta: Mutiara Sumber Ilmu, 1996)

Sutrisno PH, Falsafah Hidup Pancasila (Yogyakarta: Pandawa, 1977)

Syofyan,Donny, Dinasti Demokrat dan Anarki Famili,TEMPO.CO, 15 Mei 2013

M. Sungaidi, Dosen Fakultas Ilmu Dakwah dan Ilmu Komunikasi UIN Syarif Hidayatullah Jakarta. Email: muhammad.sungaidi@uinjkt.co.id 